\title{
HANDREIKING VOOR
}

\section{COMMUNICATIE BIJ DEMENTIE}

Een nieuwe handreiking geeft verzorgenden en verpleegkundigen adviezen om beter te communiceren met mensen met dementie, mantelzorgers en collega's. Communicatie met mensen met dementie, hun mantelzorgers en betrokken zorgprofessionals bevat tips en animatievideo's over het omgaan met mensen met dementie en hun mantelzorgers. Ook geeft het document handvatten over hoe zorgprofessionals met elkaar de zorg goed kunnen afstemmen. De handreiking is bedoeld voor zorgprofessionals in de thuissituatie, zoals casemanagers dementie en wijkverpleegkundigen, in het verpleeghuis en in het ziekenhuis. De tips zijn in samenwerking met zorgprofessionals ontwikkeld en in de praktijk getest. De handreiking is een samenwerking van het Trimbos-instituut, Nivel, Vilans, Alzheimer Nederland en V\&VN. Download de handreiking gratis op www.alzheimer-nederland.nl (zoek op handreiking communicatie dementie).



Meer nieuws op:

\section{Dagelijks morfine verbetert kwaliteit van leven bij COPD}

\section{CLIËNTEN MET DYSPNEUKLACHTEN BIJ ERNSTIGE COPD KUNNEN BAAT HEBBEN BIJ DAGELIJKSE MORFINETABLETTEN. DAT CONCLUDEREN NEDERLANDSE ONDERZOEKERS.}

Morfine vermindert het gevoel van kortademigheid dat cliënten met COPD parten speelt in hun dagelijkse bezigheden. En dus bestudeerden onderzoekers of morfine de kwaliteit van leven zou kunnen verbeteren bij mensen met ernstige COPD. De cliënten die meededen aan het onderzoek hadden bij het begin matige tot zeer ernstige dyspneuklachten, ondanks optimale behandeling met en zonder medicijnen. De helft slikte twee- tot driemaal daags $10 \mathrm{mg}$ morfine, de andere helft kreeg een placebo. De eerste groep rapporteerde

na vier weken een hogere kwaliteit van leven dan de tweede. De cliënten met de ernstigste dyspneuklachten gaven ook aan minder benauwd te zijn bij een dagelijkse dosis morfine.

Cliënten met minder ernstige dyspneu merkten geen effect op hun benauwdheid. 'Artsen zijn, zeker bij mensen met chronische longziekten, vaak bang voor een negatief effect van morfine op de ademhaling', vertelt onderzoeker en specialist ouderengeneeskunde en kaderarts Daisy Janssen. Volgens Janssen en haar mede-onderzoekers is dit onterecht. 'In ons ons onderzoek hebben we hier heel zorgvuldig naar gekeken. We hebben gezien dat een lage dosis morfinetabletten, ook bij mensen met ernstige COPD, geen nadelig effect heeft op de ademhaling.' De onderzoeksresultaten zijn in augustus 2020 gepubliceerd in het wetenschappelijke tijdschrift JAMA Internal Medicine. De onderzoekers zijn verbonden aan de Universiteit Maastricht en aan Ciro, expertisecentrum voor onder andere chronische longaandoeningen. 


\section{(4) 90+ EN THUISWONEND}

Op de foto: een thuiswonende

90-plusser wordt gevaccineerd tegen corona. In Noorwegen stierven tientallen verpleeghuisbewoners na hun prik. Volgens de Noorse gezondheidsautoriteiten was er geen verband tussen de vaccinatie en sterfgevallen. Ook Nederlandse experts zien geen reden te stoppen met het vaccineren van de alleroudsten. Hoogleraar ouderengeneeskunde \& ethiek van de zorg Cees Hertogh: 'Voor ouderen die palliatieve zorg ontvangen of een heel beperkte levensverwachting hebben, is het aan een arts om per individueel geval een wijze beslissing te nemen, in overleg met de patiënt en familie. Dat was zo en dat blijft zo.'

2

\section{$46 \%$}

van de ouderen vindt het niet prettig dat ze steeds meer moeten regelen via internet, blijkt vit onderzoek van $K B O-P C O B$.

\section{$6,83 \%$}

was het verzuimpercentage van zorgpersoneel in 2020, het hoogste sinds 2004. In 2019 was het 6,14 procent.

\section{0}

jaar duurt het grootschalige onderzoek naar dementie dat

ZonMw begint. Het onderzoek kijkt naar het verloop van dementie en preventie.

\section{'Aspirine tegen} COVID-vermoeidheid'

Aspirine helpt mogelijk tegen vermoeidheidsklachten door corona. Dit zegt ic-arts Diederik Gommers in de podcast Virusfeiten. Ex-coronapatiënten blijven voornamelijk last hebben van vermoeidheid. Gommers merkt dat het virus kan zorgen voor trombose in de longen: 'Er komen dan bloedpropjes in de kleine vaten van de longen, die groter kunnen worden. Als je rustig zit, gaat het best aardig. Maar zodra je je inspant, kom je zuurstof tekort. Voor deze longembolieën hebben we bloedverdunners.' De bloedverdunners kunnen in de thuissituatie niet worden gebruikt, omdat ze mogelijk andere klachten geven. Gommers: 'Als je bijvoorbeeld op je hoofd valt, kun je extra bloedingen krijgen.' De ic-arts vertelt dat wanneer je besmet bent met COVID-19 en aspirine slikt, dit preventief kan werken bij het ontwikkelen van trombose en dus vermoeidheid. 'Er loopt nu een grote internationale studie op dit vlak, en die resultaten wachten we eerst af voordat we hier officieel advies over uitbrengen.'






\section{ACTUEEL}

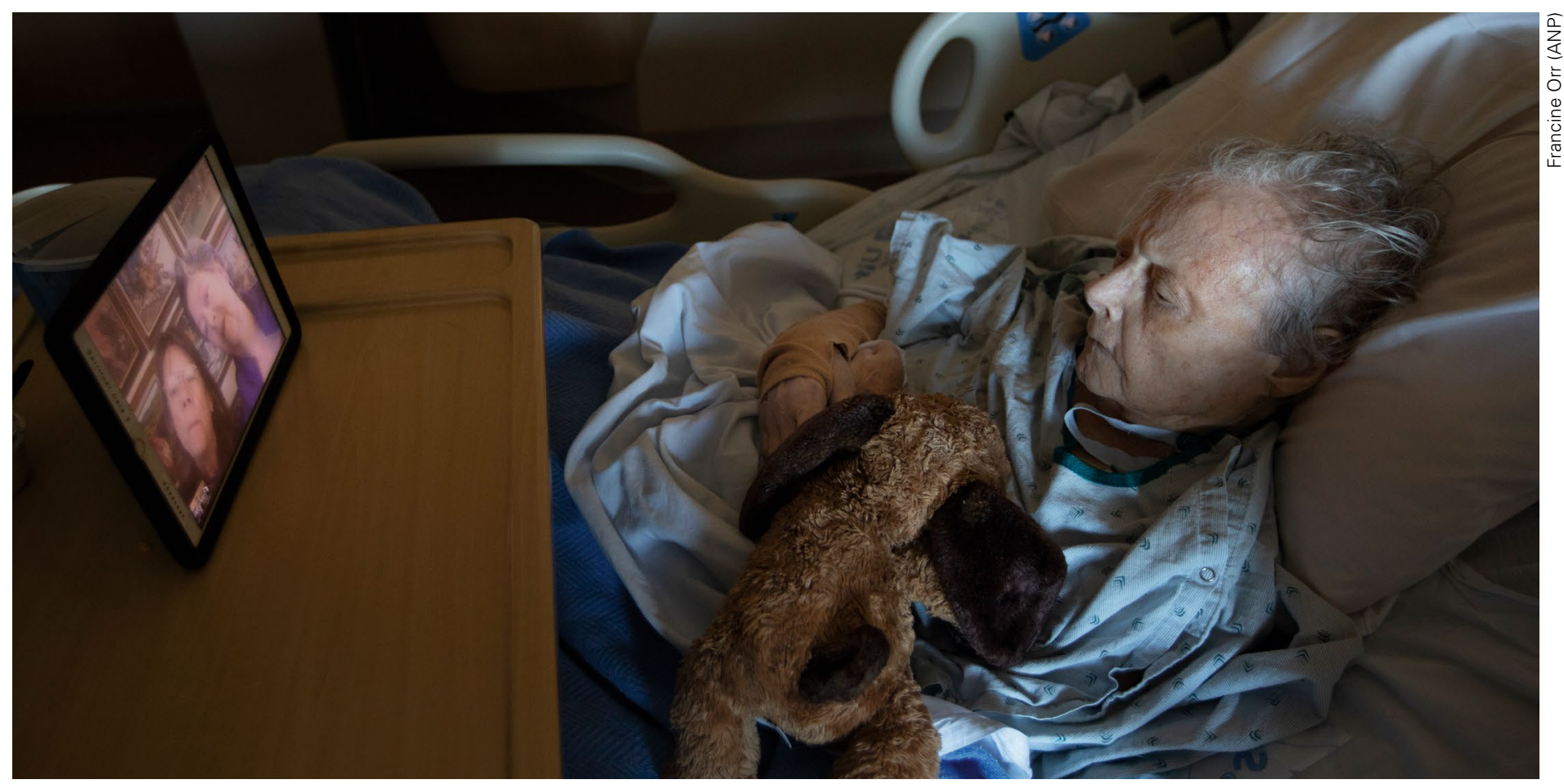

\section{101-JARIGE OVERLEEFT CORONA ÉN GEBROKEN HEUP}

De 101-jarige Marjorie Leach houdt in het ziekenhuis haar knuffel Poofey Woo stevig vast terwijl ze naar een videoboodschap van haar dochter kijkt. De Amerikaanse herstelde van een gebroken heup in het verpleeghuis, toen ze besmet werd met het coronavirus. Inmiddels is ze genezen en thuis bij haar dochter.

\section{'Weinig kennis over NAH stimuleert agressie'}

\section{BIJ CLIËNTEN MET NAH IS MEESTAL WEINIG AANDACHT VOOR HET MENTALE WELZIJN. DIT KAN AGRESSIEF GEDRAG IN DE HAND WERKEN.}

Dit stelt docent hersenletsel Arno Prinsen. Veel mensen met NAH hebben geen of beperkt ziekte-inzicht. Dit betekent dat zij zich niet realiseren dat ze minder kunnen dan voorheen. Dat kan zorgen voor frustratie en depressieve gevoelens. Vaak hebben verzorgenden weinig kennis over dit beperkte ziekte-inzicht. 'De cliënt kan zich dan heel alleen voelen en soms zelfs achterdochtig raken', vertelt Prinsen. 'Zo kan er verbale en soms zelfs fysieke agressie ontstaan.' Prinsen pleit voor meer scholing over het beperkte ziekte-inzicht, zodat verzorgenden het gedrag van hun cliënt beter kunnen plaatsen en het niet persoonlijk nemen. En zo kunnen verzorgenden ook beter op het gedrag reageren, stelt Prinsen. Hij bedacht hiervoor een methode die uit verschillende stappen bestaat: aansluiten, gedachten ordenen en dan komen de oplossingen, die je samen met de cliënt bedenkt. Lees zijn tips op www.tvvtotaal.nl (zoeken op: NAH).

\section{HELPEN BIJ VERDRIET EN ROUW TIJDENS CORONA}

Rouwdeskundige Manu Keirse maakte een extra hoofdstuk bij het boek Helpen bij verlies en verdriet met handvatten voor wie mensen in rouw en verdriet wil bijstaan in tijden van corona. Keirse schreef de gratis download naar aanleiding van de corona-

crisis: 'De COVID-19 pandemie heeft

ingrijpende gevolgen voor heel veel mensen', vertelt hij. 'We rouwen om het verlies van dierbaren, in erg moeilijke omstandigheden. In dit boekje wil ik enkele praktische handvatten aanreiken om mensen

in rouw in deze uitdagende tijden bij te

staan. Elkaar niet kunnen zien of aanraken is

zwaar. Tegelijkertijd zijn er wel andere manieren om te steunen.'

Download het hoofdstuk via www.tvvtotaal. $\mathrm{nl}$ (zoeken op: Manu Keirse). 